\title{
Note
}

\section{First Record of the Land Snail Pristiloma idahoense (Gastropoda: Pristilomatidae) for Montana}

\author{
PAUL HENDRICKS
}

Philip L. Wright Zoological Museum, Division of Biological Sciences, University of Montana, Missoula, Montana 59812 USA; email: paul.hendricks@umontana.edu

Hendricks, Paul. 2016. First record of the land snail Pristiloma idahoense (Gastropoda: Pristilomatidae) for Montana. Canadian Field-Naturalist 130(3): 199-201.

The land snail Pristiloma idahoense (Pilsbry, 1902) is reported from Montana for the first time. Five live individuals were found under downed wood beneath a mature coniferous forest canopy at $1670 \mathrm{~m}$ elevation in the Big Creek drainage of the Bitterroot Mountains, Ravalli County, Montana. This location extends the known range approximately $75 \mathrm{~km}$ east and over the crest of the Bitterroot Mountains from the nearest sites in Idaho County, Idaho and supports the hypothesis that the terrestrial mollusc fauna of Montana west of the continental divide has been strongly influenced by a molluscan radiation, which developed in a northern Idaho Pleistocene refuge. The probable route of dispersal for P. idahoense between the Bitterroot Mountains of Montana and the adjacent Lochsa River drainage of Idaho was over the lower mountains to the north in the Lolo Pass area.

Key Words: Distribution; Montana; Pristiloma idahoense; Pristilomatidae; range extension; terrestrial gastropod; land snail

Pristiloma idahoense (Pilsbry, 1902), the Thinlip Tightcoil, is a small land snail found primarily in northern Idaho, with additional records from northeastern Oregon and northeastern Washington (Pilsbry 1902; Baker 1932; Frest and Johannes 1995, 1997; Bosworth 2012; Burke 2013). NatureServe (2015) lists P. idahoense with a global rank of G2G3 (vulnerable to imperilled), and a state rank of S1 (critically imperilled) in Idaho, S2? (imperilled) in Washington, and SNR (not ranked) in Oregon. Recent surveys by the Idaho Department of Fish and Game (M. Lucid, personal communication) show that the species is widely distributed, although relatively rare, across the northern Idaho Panhandle and also extant in extreme northeastern Washington. Extensive surveys for land molluscs in Montana west of the continental divide began in 2005 and resulted in detections of a number of rare taxa of the Washingtonian Province with ranges primarily in Idaho (Frest and Johannes 2000; Hendricks et al. 2007; Hendricks 2012; Burke 2013). However, P. idahoense was not one of the species found during the Montana surveys, nor has it been recorded previously in the state. Here, I document the first occurrence of $P$. idahoense in Montana and discuss the biogeographic significance of this discovery.

On 2 June 2015 I found five live P. idahoense at one location in the Selway-Bitterroot Wilderness, Ravalli County, Montana, just north of the juncture of the trails leading to Big Creek Lakes and South Fork Lake in the Big Creek drainage of the Bitterroot Mountains. The site $\left(46.48790^{\circ} \mathrm{N}, 114.34541^{\circ} \mathrm{W}\right)$ is on the eastern side of the Bitterroot Mountains (the crest of which forms the boundary between Idaho and Montana) about $1.0 \mathrm{~km}$ southeast of the outflow of Big Creek Lakes at $1670 \mathrm{~m}$ elevation. Two of the five snails were collected and preserved in $95 \%$ ethyl alcohol and later deposited in the mollusc collection at the Carnegie Museum of Natural History (CM 144502). The Montana voucher specimens are typical in size and external morphology for $P$. idahoense (Burke 2013; T. Burke, personal communication). The shells are low conic, 3.2 and $3.5 \mathrm{~mm}$ in diameter and 1.8 and $2.1 \mathrm{~mm}$ in height, tightly coiled with about 6.0 and 6.25 whorls, possess distinct shoulders, and are imperforate (Figure 1). Pristiloma idahoense is readily distinguished by its imperforate shell and distinct shoulder from the other Pristiloma species reported previously in Montana (Berry 1919; Russell and Brunson 1967; Hendricks 2012): P. chersinella and P. wascoense.

The Montana location extends the range of $P$. idahoense about $75 \mathrm{~km}$ east and over the crest of the Bitterroot Mountains from the closest known Idaho locality at Dipper Creek $\left(46.35553^{\circ} \mathrm{N}, 115.29161^{\circ} \mathrm{W}\right) 5 \mathrm{~km}$ northeast of the historical Lochsa Ranger Station in Idaho County (Bosworth 2012; M. Lucid, personal communication), where John Slapcinsky collected a single shell (Florida Museum of Natural History: FLMNH 444802) on 9 July 2010. Forest canopy cover at the Montana site was about $70 \%$, composed predominantly of mature Engelmann Spruce (Picea engelmannii), Subalpine Fir (Abies lasiocarpa), and Douglas-fir (Pseudotsuga menziesii), with a ground cover including patches of ferns and moss. The snails were under a piece of wood on the forest floor within $50 \mathrm{~m}$ of a small seepage.

Other mollusc species found in close proximity $(<30 \mathrm{~m})$ were Udosarx lyrata (Lyre Mantleslug), Radiodiscus abietum (Fir Pinwheel), and Discus whitneyi (Forest Disc). Habitat at the Montana site differs

A contribution towards the cost of this publication has been provided by the Thomas Manning Memorial Fund of the Ottawa Field-Naturalist's Club. 

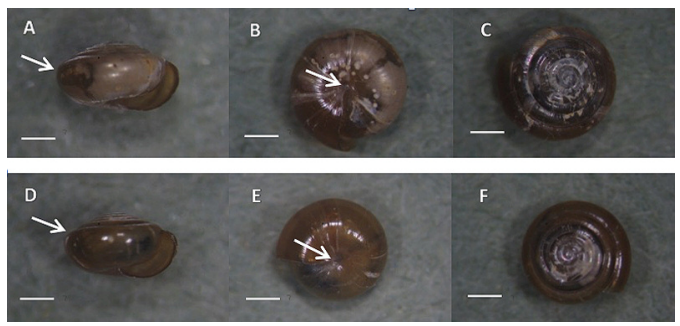

FIgURE 1. The two voucher specimens of Pristiloma idahoense (Carnegie Museum of Natural History: CM 144502) from the Big Creek drainage in the Bitterroot Mountains, Ravalli County, Montana. The prominent shoulder on the shells is indicated by arrows in A and D, the imperforate shell (lack of an open umbilicus) by arrows in $\mathrm{B}$ and $\mathrm{E}$, and the number of whorls in $\mathrm{C}$ and $\mathrm{F}$. Scale bar $=1 \mathrm{~mm}$. Photo: T. Burke.

somewhat from those described elsewhere for the species, which indicate that $P$. idahoense has been found most often at lower elevations in moist forest zones under mature, closed-canopy Ponderosa Pine (Pinus ponderosa), Douglas-fir or Grand Fir (Abies grandis), and Pacific Yew (Taxus brevifolia), sometimes in mossy talus and under coarse organic debris, and sometimes in association with limestone and basalt (Baker 1932; Frest and Johannes 1995, 1997, 2000; Bosworth 2012; Burke 2013).

The discovery of $P$. idahoense in Montana is not surprising, but the location of this first occurrence is unexpected. Pristiloma idahoense has been documented within $2 \mathrm{~km}$ of Montana on the Idaho side of Lookout Pass (1440 m elevation) near Mullen, Shoshone County (Bosworth 2012; M. Lucid, personal communication), about $150 \mathrm{~km}$ northwest of the Montana location. The mountains of Montana along the boundary with Idaho north of Lookout Pass include the low-elevation valleys of the Clark Fork and Kootenai Rivers (at about $645 \mathrm{~m}$ and $555 \mathrm{~m}$, respectively) and a number of lowelevation passes between $1440 \mathrm{~m}$ and $1525 \mathrm{~m}$, thus affording suitable routes for dispersal into Montana. Pristiloma idahoense probably occurs in Montana north of Lookout Pass and efforts to confirm occurrence in that region should be made. From Lookout Pass south to Lolo Pass $(1596 \mathrm{~m})$, the boundary between Montana and Idaho is generally higher than $1920 \mathrm{~m}$, with no river valleys and only a few passes dropping below $1825 \mathrm{~m}$ elevation. Nevertheless, it is possible that $P$. idahoense has reached Montana across this mountainous divide because it is forested in many places; additional surveys for the species are warranted in this area.

South of Lolo Pass to Lost Trail Pass (2138 m), the crest of the Bitterroot Mountains (which is part of the granitic Idaho Batholith) has numerous summits between 2500 and $2830 \mathrm{~m}$ near or above tree line and rarely drops below $2100 \mathrm{~m}$, such that the Bitterroot Mountains form a significant alpine barrier to land mollusc dispersal between Idaho and Montana. Further- more, most drainages in the Bitterroot Mountains, including Big Creek where $P$. idahoense was discovered, were glaciated during the Pleistocene from the crest down to $1220 \mathrm{~m}$, below which elevation the Bitterroot Valley was inundated by water from Glacial Lake Missoula (Alden 1953), unlike many of the documented $P$. idahoense sites in Idaho, which appear to have remained unflooded and ice-free. Thus, the probable route of dispersal for $P$. idahoense between the Bitterroot Mountains of Montana and the adjacent Lochsa River drainage of Idaho is over the lower mountains to the north in the Lolo Pass area.

The presence of $P$. idahoense in Montana is yet another indication that the terrestrial mollusc fauna in the state west of the continental divide has been strongly influenced by a molluscan radiation, which developed in a northern Idaho Pleistocene refuge (Leonard et al. 2003; Shafer et al. 2010). Pristiloma idahoense can be added to the Montana list of regional endemic mollusc taxa with close affinity to northern Idaho (Frest and Johannes 1995, 2000; Hendricks 2012; Burke 2013), which includes the slugs Hemphillia camelus (Pale Jumping-slug), Hemphillia danielsi (Marbled Jumpingslug), Kootenaia burkei (Pygmy Slug), Magnipelta mycophaga (Magnum Mantleslug), Prophysaon humile (Smoky Taildropper), Udosarx lyrata, and Zacoleus idahoensis (Sheathed Slug), and the land snails Allogona ptychophora (Idaho Forestsnail), Cryptomastix mullani (Coeur d'Alene Oregonian), Polygyrella polygyrella (Humped Coin), and Radiodiscus abietum.

\section{Acknowledgements}

Steve Schlang accompanied me in the field and helped with mollusc surveys during this discovery. Mike Lucid and Bill Bosworth (Idaho Department of Fish and Game) provided me with Idaho records of Pristiloma idahoense through 2010 and shared preliminary results of additional mollusc surveys conducted by the Idaho Department of Fish and Game in northern Idaho and adjacent regions. Tom Burke (U.S. Forest Service, retired) verified my initial identification of the voucher specimens and took the photographs of them, and Timothy Pearce arranged for their rapid processing and deposit in the mollusc collection at the Carnegie Museum of Natural History, Pittsburg, Pennsylvania. An earlier version of the manuscript benefited from the thoughtful comments of Donald McAlpine and two anonymous reviewers. I thank them all.

\section{Literature Cited}

Alden, W. C. 1953. Physiography and glacial geology of western Montana and adjacent regions. Professional paper 231. United States Geological Survey, Reston, Virginia, USA.

Baker, H. B. 1932. New land snails from Idaho and eastern Oregon. Nautilus 45: 82-87.

Berry, S. S. 1919. Mollusca of Glacier National Park, Montana. Proceedings of the Academy of Natural Sciences of Philadelphia 71: 195-205. 
Bosworth, W. 2012. Terrestrial gastropods of USFS Northern Region: materials developed for Idaho field guide. Idaho Fish and Game, Boise, Idaho, USA.

Burke, T. E. 2013. Land Snails and Slugs of the Pacific Northwest. Oregon State University Press, Corvallis, Oregon, USA.

Frest, T. J., and E. J. Johannes. 1995. Interior Columbia Basin mollusk species of special concern. Final report to Interior Columbia Basin Ecosystem Management Project. Deixis Consultants, Seattle, Washington, USA.

Frest, T. J., and E. J. Johannes. 1997. Land snail survey of the lower Salmon River drainage, Idaho. Technical bulletin 97-18. Idaho Bureau of Land Management, Boise, Idaho, USA.

Frest, T. J., and E. J. Johannes. 2000. An annotated checklist of Idaho land and freshwater mollusks. Journal of the Idaho Academy of Science 36: 1-51.

Hendricks, P. 2012. A guide to the land snails and slugs of Montana. Report to the US Forest Service, Region 1. Montana Natural Heritage Program, Helena, Montana, USA.

Hendricks, P., B. A. Maxell, S. Lenard, and C. Currier. 2007. Land mollusk surveys on the USFS Northern Region lands: 2006. Report to the USDA Forest Service, North- ern Region. Montana Natural Heritage Program, Helena, Montana, USA.

Leonard, W. P., L. Chichester, J. Baugh, and T. Wilke. 2003. Kootenaia burkei, a new genus and species of slug from northern Idaho, United States (Gastropoda: Pulmonata: Arionidae). Zootaxa 355: 1-16.

NatureServe. 2015. NatureServe Explorer: an online encyclopedia of life. Version 7.1. NatureServe, Arlington, Virginia, USA. Accessed 5 December 2015. http://explorer.natureserve.org.

Pilsbry, H. A. 1902. New land mollusca from Idaho. Proceedings of the Academy of Natural Sciences of Philadelphia 54: 593 .

Russell, R. H., and R. B. Brunson. 1967. A check-list of molluscs of Glacier National Park, Montana. Sterkiana 26: 1-5.

Shafer, A. B. A., C. I. Cullingham, S. D. Côté, and D. W. Coltman. 2010. Of glaciers and refugia: a decade of study sheds new light on the phylogeography of northwestern North America. Molecular Ecology 19: 4589-4621.

Received 25 June 2015

Accepted 27 June 2016 